\title{
O Livro de Compromisso entre os manuscritos confrariais: potencialidades para o trabalho filológico
}

Fábio César Montanheiro*

RESUMO: A partir da análise de alguns Livros de Compromisso pertencentes ao Arquivo Eclesiástico da Paróquia de N.S. do Pilar de Ouro Preto, ao Museu da Inconfidência, ao Arquivo Casa dos Contos e ao Arquivo Eclesiástico da Arquidiocese de Mariana, este artigo trata de documentação gerada pelas irmandades religiosas leigas das Minas setecentistas. Instituições oficialmente reconhecidas, tanto pela instância religiosa quanto pela civil, as irmandades tinham suas atividades registradas em livros específicos. Com isso, legaram vasto acervo documental manuscrito ainda pouco explorado como objeto de estudo filológico. Inicialmente, este trabalho discorre sobre a instituição irmandade, sobre a gama documental por elas produzida, dando destaque ao Livro de Compromisso, e apresenta uma proposta para compreensão de compromisso que permita entender não só o lugar ocupado por esse Livro frente aos demais manuscritos confrariais, mas também sua constituição. Em seguida, destaca aspectos recorrentes nos Compromissos produzidos pelas irmandades, como a variação ortográfica, a guarda e leitura dos livros, a existência de cópias e traslados de Compromissos, suas temáticas comuns e as provisões que incidiam sobre eles.

PALAVRAS-CHAVE: Documentos confrariais; Livros de Compromisso; irmandades mineiras; manuscritos setecentistas em língua portuguesa.

Breve histórico sobre a origem das irmandades

medievalista francês Georges Duby atribui o surgimento de confrarias à solidariedade buscada por indivíduos quando deslocados de suas origens, por terem perdido sua primitiva rede de solidariedade familiar e local. Tomando a França como exemplo, o historiador diz que, no século XII, na periferia das cidades em crescimento,

\footnotetext{
Universidade Federal de São Carlos-fcmonta@uol.com.br .
} 
irrompe a fome entre migrantes, desenraizados, sós. Para socorrê-los, instituições de caridade, albergues e Santas Casas foram criadas. "Formaram-se as confrarias, as associações de socorro mútuo, reconstituindo uma malha de solidariedade nos novos bairros" (Duby, 1999, p.33).

Em Portugal, o modelo por excelência das irmandades foram as Santas Casas de Misericórdia. Voltadas ao "exercício da caridade para com o próximo, as Misericórdias cuidavam de doentes desassistidos, de defuntos carentes de recursos, de presos e de condenados". Muitas vezes associadas às corporações de ofício, Boschi também salienta que não devemos entender as confrarias como extensão delas. Embora muitas tenham tido origem nos ofícios, elas podem, quando muito, ser entendidas como suas "faces religiosas" (Boschi, 1986, p.13).

As associações religiosas leigas receberam variada terminologia, ${ }^{1}$ a ponto que nem mesmo a Cúria Romana fazer claras distinções entre elas (Boschi, 1986, p.14). Para o presente estudo, convém, no entanto, estabelecer a distinção apenas entre irmandades - e adotaremos confraria como seu sinônimo - e ordem terceira, de que não trataremos aqui, senão perifericamente. Enquanto nas irmandades

\footnotetext{
o objetivo é o de incrementar o culto público, as ordens terceiras são associações pias que se preocupam, fundamentalmente, com a perfeição da vida cristã de seus membros. Embora vivendo no século, os terceiros se vinculam a uma ordem religiosa, da qual extraem e adaptam regras para uma vida cristã no mundo. (Boschi, 1986, p.19)
}

Ademais, irmandades respondiam ao bispo diocesano, subordinandose ao clero secular, ao passo que ordens terceiras respondiam aos provinciais da ordem monástica à que se filiavam, subordinando-se, portanto, ao clero regular.

\footnotetext{
A pluralidade de denominações em torno dessa instituição provém de longa data. "Les institutions que nous désignons aujourd'bui sous le nom de confréries, ont porté autrefois bien des noms différents. On trouve dans les Conciles, du douzième au seizième siècle un grand nombre d'expressions qui indiquent la même chose. On les appelait: Fratantiœ, Confratantiœ, Fratriœ, Frateriœ, Confrateriœ, Confratriœ, Colligationes, Conjurationes, Sodalitates, Congregationes, Societates, Scholœ, Confraternitates, Collegia. [...] Dans les actes émanés du Saint-Siège depuis trois siècles, relativement aux confréries, on trouve les dénominations suivantes: Confraternitas, Sodalitas, Sodalitium, Confraternitas laicorum, Congregatio, Confœderatio, Pia Unio, Societas, Cœtus, Consociationes." Logo em seguida, o autor declara que "Ces noms sont employés indifféremment les uns pour les autres dans des actes différents concernant de véritables confréries, et quelques fois dans la même pièce [...]." (Tachy, 1898, p. 2-3).
} 
As irmandades no Brasil partiram de modelos portugueses. Embora seus regulamentos fossem semelhantes àqueles das Misericórdias portuguesas, não dispunham da mesma solicitude e abnegação destas, pois procuravam "promover o benefício dos próprios membros, sem tentar favorecer pessoas estranhas ao grêmio" (Scarano, 1975, p.27).

\section{As irmandades nas Minas do século XVIII}

Presente em todo o Brasil colonial, o fenômeno confrarial logrou um contorno diferenciado na capitania das Minas, onde teria aportado juntamente com seus descobridores bandeirantes. Ao contrário do litoral, onde havia mosteiros de grandes ordens monásticas para propagação da religião, tais como os dos jesuítas, franciscanos, carmelitas e beneditinos, em Minas não os houve, por interdito régio, pois os representantes dessas casas religiosas foram acusados, logo nos primórdios da exploração aurífera, de terem parte no extravio do ouro, não apenas desencaminhando o metal da cobrança dos impostos reais, mas também instilando a população para que como tal procedesse (Holanda, 1960, p. 277). Por essa razão, foram banidos do território e proibidos de ali instalarem seus conventos e mosteiros.

As ordens monásticas dispunham de recursos próprios, provindos de suas matrizes européias. Não havendo, portanto, quem fomentasse e financiasse o estabelecimento da Igreja nas Minas, os adventícios tomaram a si essa função. O rei português, que, por deter o padroado régio e o Grão-Mestrado da Ordem de Cristo, era responsável pela arrecadação dos dízimos e pela expansão da Santa Fé Católica em suas possessões (Oliveira, 1964), teria estimulado a criação de irmandades a fim de, por meio delas, transferir ao próprio povo os dispendiosos encargos que the cabiam na esfera religiosa (Salles, 1963, p. 27).

Não foi apenas com vistas a poupar recursos amealhados com os dízimos eclesiásticos que a Coroa portuguesa incentivou as irmandades. Um outro fator consistia na canalização de conflitos e contradições do sistema colonial para o interior dessas instituições, estimuladas e, portanto, vigiadas ao mesmo tempo, pois procurava-se evitar qualquer aspiração de independência em seu interior. Nelas o Estado encontrou um lenitivo que neutralizaria revoltas originadas pelo fisco e pela presença de tropas, e que minimizaria as tensões sociais do desequilibrado cotidiano do sistema colonial. Boschi sintetiza esse aspecto concluindo que, por meio das irmandades, a Coroa 
não foi fator de contestação do Antigo Regime. Ao contrário, o que se verifica é que, por intermédio das irmandades, a religião em Minas Gerais permaneceu sendo um de seus sustentáculos [...]. (1987, p.142)

As irmandades estiveram tão presentes nas comunidades mineiras desde sua origem, que Salles atrela a importância de seu estudo à compreensão da formação de Minas Gerais. Afirma ele que não

\begin{abstract}
se poderia, portanto, estudar a evolução social de Minas, suas peculiaridades, sua dinâmica própria, suas projeções históricas, sua influência no comportamento social e político da coletividade mineira contemporânea, sem, antes de tudo, estudar a história das irmandades religiosas. Constituíram estas a mais viva expressão social da capitania, da província e mesmo do Estado. (1963, p.126)
\end{abstract}

Foram muito numerosas as agremiações religiosas que se desenvolveram em Minas. Boschi, em sua obra a respeito da relação entre tais sodalícios e a política colonizadora em Minas Gerais, listou um total de 322 irmandades na capitania ao longo dos séculos XVIII e albores do XIX. Organizadas desde o início do povoamento, as primeiras a se constituírem foram a do Santíssimo Sacramento e a de N.S. do Rosário. Da primeira faziam parte os irmãos brancos abastados, da segunda, os pretos forros ou cativos, para seguirmos denominação usual da época. Em termos quantitativos, o orago de N.S. do Rosário foi, segundo Boschi, o mais numeroso nas Gerais: 62 irmandades, ou 19,31\% do total listado pelo historiador; o do Santíssimo Sacramento figura logo em seguida, totalizando 43 associações, o que corresponde a 13,39\% do total. Uma terceira devoção bastante freqüente em Minas foi a de São Miguel e Almas, com 35 irmandades identificadas ou 10,90\% sobre o total de 322 (Boschi, 1986, p.187-8). Embora essae orago fosse muito popular, suas irmandades eram seletivas quanto aos componentes que a elas se filiavam, constituindo-se "mormente por homens brancos dotados de posse [...] tal qual as irmandades de Misericórdia da época considerada" (Campos, 1994, p.4). ${ }^{2}$

2 Campos (1994) destaca que essa ordenação numérica no tocante à predileção de devoções também se deu em Portugal e na França. Quanto à terceira devoção, o culto a São Miguel e Almas, informa que o Concílio Tridentino reiterou o culto aos coros angélicos e às almas do Purgatório e que, entre os anjos, Miguel é o maior deles (p. 159). 


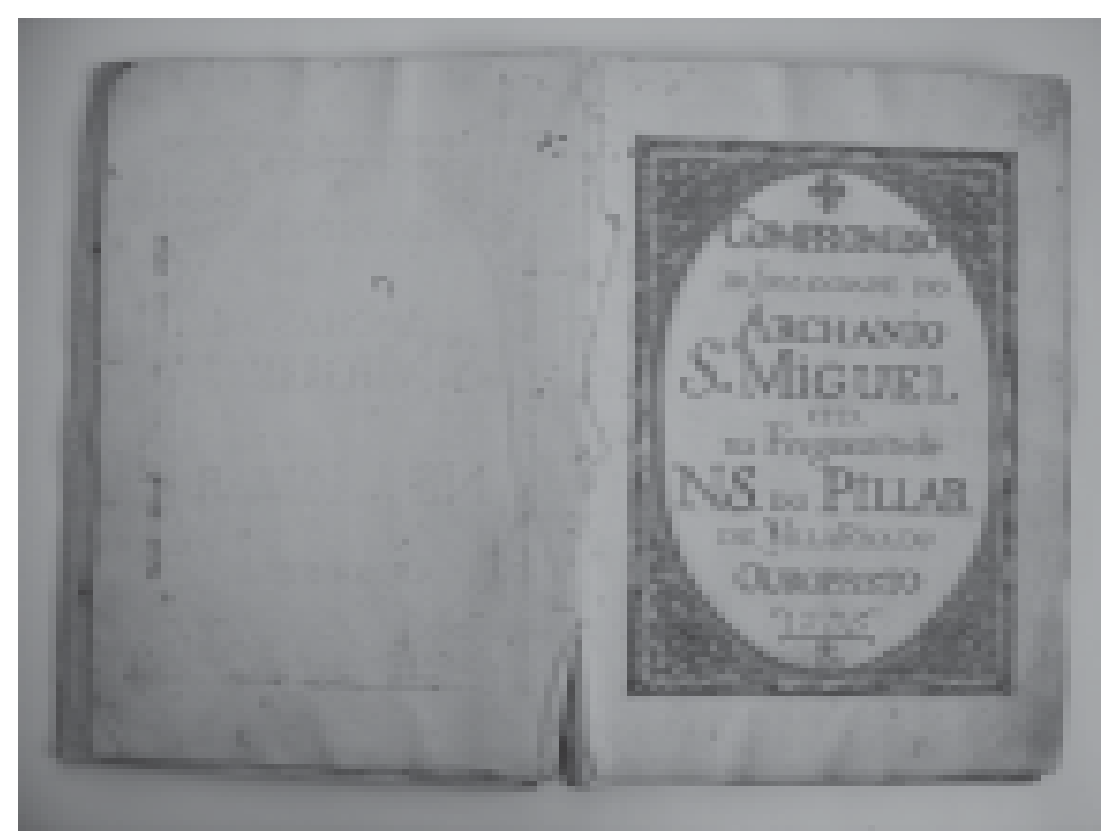

Figura 1 "Frontispício do Compromisso da Irmandade do Arcanjo S.Miguel da Freguesia de N.S. do Pilar do Ouro Preto.

Mas as associações religiosas leigas não se restringiam a agregar apenas esses dois polos étnico-sociais. Outros oragos houve que, a julgar pela sua denominação, acolhiam mestiços, como a "Irmandade do Patriarcha S. Joze dos bem Cazados Erigida pelos Pardos de Villa Rica no Anno de 1730", que salienta, assim como a do Rosário, sua predileção epidérmica quanto àqueles que nela se afiliassem. Anteriormente à situação social ou profissional de cada indivíduo, era a condição racial que determinava a admissão de associados a uma ou outra agremiação. Segundo Scarano,

[o]s diversos grupos irão formar-se tendo como base principal de sua divisão a cor da pele, que se confunde em grande parte com a categoria sócio-econômica. [...] O branco e o negro, o senhor e o escravo constituem os extremos da escala social e étnica, enquanto os diferentes matizes no tocante à cor da pele vão determinar os graus intermediários. (1975, p.30)

Assim como na colônia uma nação e uma nacionalidade se gestavam, os adventícios como um todo, fosse na reafirmação de sua identidade fosse na busca de uma nova, viam na participação em irmandades leigas um canal para isso. Particularmente os negros cativos, arrancados com violência de sua terra 
natal, tentaram reelaborar formas de sociabilidade entre suas culturas e outras vivenciadas na colônia. Nesse sentido, "a parcela da população composta pelos africanos escravizados e seus descendentes também passava por processos de constituição de novas identidades a partir de sua incorporação na sociedade colonial escravista" (Souza, 2002, p.180). O motor que gerou o surgimento de irmandades do medievo continuava, então, atual em terras americanas, tanto para europeus que para a colônia americana se desterravam, quanto para africanos, trazidos à força.

Orago de grande popularidade entre os negros, o de N.S. do Rosário, congregava em Minas não só negros de origem vária, "forro, ou captivo, de qual quer nasção que seja", mas também apresentava tendência à abertura no tocante a etnia e gênero de seus confrades, dado aceitar em seu quadro associativo "[t]oda apessoa preta, oubranca, de hum, eoutro sexo". ${ }^{3}$

Essa relativa democratização de fundo epidérmico, ${ }^{4}$ sobretudo quanto ao caráter associativo multiétnico de seus componentes negros, que se dá de forma reiterada ao longo deste Compromisso de N.S. do Rosário dos Pretos do Ouro Preto ${ }^{5}$ se estende, de modo geral, aos Rosários de Minas, "onde as irmandades de negros parecem não refletir as clivagens étnicas no interior de populações africanas, como na Bahia" (Aguiar, 1993, p.300). Já no litoral, houve tendência a uma especialização étnica na composição do quadro associativo das irmandades de negros, em que a etnia ancestral do postulante à filiação nesta ou naquela irmandade contava. Ser preto mina, angola, moçambique ou guiné no Rio de Janeiro determinava a irmandade a que se podia filiar (Soares, 2000), assim como em Salvador os jejes tinham, por exemplo, a sua irmandade do Senhor Bom Jesus das Necessidades e Redenção, e os nagôs de nação queto, a de N.S. da Boa Morte. Segundo Reis,

[d]o ponto de vista das classes dirigentes, isso foi interessante no sentido de manter as rivalidades étnicas entre os negros, prevenindo alianças perigosas. Ao mesmo tempo, do ponto de vista dos negros, impediu-lhes a uniformização ideológica, que poderia levar a um controle social mais rígido. (1991, p.55)

Compromisso de N.S. do Rosário dos Pretos do Ouro Preto, capítulo $1^{\circ}$.

4 "Relativa", pois em Minas houve clivagem entre escravos africanos e crioulos, ou seja, entre escravos naturais da África e aqueles nascidos em terras americanas.

5 No capítulo $2^{\circ}$, ao tratar da eleição de seu Rei e Rainha, reza o Compromisso de N.S. do Rosário dos Pretos do Ouro Preto que "Haverá nesta Irmandade, hi Rey e hia Raynha, ambos pretos de qualquer Nassão que sejão [...]", o que se reafirma no capítulo $16^{\circ}$. que, ao versar sobre a eleição do Juiz e da Juíza, estabelece que “[...] serão propostos para Juis deNossaSenhora, tres Irmaõs pretos, epara Juizas tres pretas, de qual quer nasção que sejão forros, ou captivos, os mais benemeritos, e ricos da freguesia [...]". 
As irmandades, funcionando então como "agentes de solidariedade grupal”,

integravam os indivíduos e liberavam seus anseios de libertação, passando, assim, a ser também o canal de manifestação de seus membros, o veículo de suas queixas, o palco de suas discussões. Isto se dá, particularmente, em relação às irmandades de negros [...]. (Boschi, 1986, p.14)

Além da questão "solidariedade grupal", o pertencimento a uma ou mais irmandades também visava evitar que suspeitas de heresia, aloteísmo e apostasia recaíssem sobre os colonos. Para não serem confundidos ou identificados como cristãos-novos, os brasileiros

criaram um catolicismo ostensivo, patente aos olhos de todos, praticado sobretudo em lugares públicos, bem pronunciado e cheio de invocações ortodoxas a Deus, Nossa Senhora, os santos. Todos tinham que ser 'muito católicos' para garantir a sua posição na sociedade, e não cair na suspeita de 'heresia'. (Hoornaert, 1974, p.16)

Contudo, da mesma forma como o Estado se impôs politicamente na América Portuguesa nesse primeiro século da civilização mineira, passa a se impor igualmente às irmandades, organizações que, tendo se originado, nas Minas, de maneira espontânea, sem imposição da Metrópole, "de baixo para cima, de livre vontade dos habitantes", poderiam se configurar em perigo constante para o Estado, razão pela qual ele procurou controlá-las (Boschi, 1986, p.29). Se durante a primeira metade do século XVIII era à autoridade eclesiástica que elas exibiam seus Livros de Compromisso para os terem aprovados, na segunda metade do século é ao rei, por intermédio de seu tribunal da Mesa da Consciência e Ordens, que elas recorrem para confirmação deles. Evidente expressão da canalização do vigor das irmandades que, desse modo, são patenteadas pela Coroa "como órgãos auxiliares - para o controle e o exercício - do poder real que não a contestasse, nem se lhe resistisse" (Boschi, 1986, p.55).

As irmandades regulavam-se por seus estatutos, reunidos num livro denominado Compromisso, que, uma vez elaborado, aprovado e confirmando, com emendas ou sem, colocava as irmandades numa situação de paridade institucional, i.e., na esfera jurídica, elas equivaliam entre si, congregassem elas elementos brancos abastados, mulatos ou negros escravos (Scarano, 1975, p.34). Esse Compromisso teria validade - ao menos em tese - até a redação de uma outra versão, quando a irmandade percebesse sua insuficiência para continuar a geri-la. Como veremos, entre todos manuscritos confrariais, o Compromisso era o único que recebia acabamento artístico, sendo alguns deles cuidadosamente iluminados. 


\title{
O Compromisso entre os manuscritos confrariais
}

López Gutiérrez \& Rodríguez Mateos (1993), centrando seus estudos em irmandades e confrarias sevilhanas, salientam sua preocupação diante da pouca atenção desferida aos documentos produzidos no ambiente confrarial e à falta de estudos científicos em torno deles, embora haja estudos de ordem histórica ou artística a respeito das irmandades e seus legados. Procuram os autores, ao apresentar este estudo sobre o patrimônio documental nas irmandades, "reclamar una merecida atención hacia este patrimonio, condenado ya en muchos casos" (p.16), com vistas a "abrir una puerta a la atención y el interés sobre el patrimonio documental de Hermandades y Confradías, tan olvidado" (p.18).

Já Silva y Verástegui, em trabalho monográfico a respeito de manuscritos ilustrados remanescentes na atual região espanhola de Navarra, informa que, entre os manuscritos compulsados, encontram-se estatutos confrariais, o que apontaria para uma distinção do Compromisso frente aos demais livros que uma irmandade tivesse, equiparando-o a livros eclesiásticos iluminados de uma ordem religiosa ou diocese, como os sacramentários, lecionários, antifonários, etc. Diz a autora que, entre

\begin{abstract}
Los documentos que fueron ilustrados con relativa frecuencia con miniaturas en esta época destacan los Estatutos por los que se regian las diversas Cofradias y Gremios, capitulo representado en el Archivo navarro por tres documentos, uno procedente del monasterio de Tulebras, relativo a la Cofradía de San Benito, de principios del siglo XIII y otros dos procedentes de la Catedral de Tudela que recogen respectivamente las Constituciones de las Cofradias de San Agustin y del Santísimo Sacramento fundadas en la Colegiata, de la primera mitad del siglo XIV. (Silva y Verástegui, 1988, p.11)
\end{abstract}

Cá como lá - tirante estudos realizados no âmbito da história econômica, social e artística, ${ }^{6}$ no campo da análise do discurso ${ }^{7}$ e da história do livro ${ }^{8}-$ , pouco se sabe a respeito de trabalhos na área de estudos filológicos que

6 Estes se focam em iluminuras presentes nos Compromissos confrariais, como os trabalhos de Esteves (1987); Perucci (1994); Campos (2005, p. 146 e 158).

7 Montanheiro (2002). Neste trabalho discorreu-se também sobre os fólios iluminados de alguns compromissos mineiros setecentistas, detendo-se a análise sobretudo sobre as letras capitulares do Compromisso dâ̂rmandade do S. S. Mîguel, e Almas doPurgatorîo da Freguezia de S.Caetano Ribeirãoabaixo Anno.M.DCC.XXII.

8 Montanheiro (2007). Neste trabalho buscou-se também realizar um trabalho filológico: a edição diplomática de três Compromissos, o das Irmandades do Arcanjo São Miguel (1735), do Santíssimo Sacramento (1738) e de N.S. do Rosário dos Pretos (1750), todos da paróquia de N.S. do Pilar do Ouro Preto, Minas Gerais. 
levem em conta essa documentação. ${ }^{9}$ É sobre ela que passamos a tecer algumas considerações.

O Livro de Compromisso era apenas um dos livros mantidos pelas irmandades. Além dele, elas possuíam outros que se destinavam ao registro de ocorrências rotineiras. A Irmandade de N.S. do Rosário dos Pretos do Ouro Preto elencou os seus no capítulo $23^{\circ}$ de seu Compromisso:

\begin{abstract}
Havemos porbem haja nesta Irman $=\mid$ dade, seisLivros grandes; asaber hum para nelle seLançar todos os annos areceita, | edespeza que houver naIrmandade; outro para selançarem as eLeyçoẽs dos officiaes, | eIrmaõs demeza, Inventarios, etermos deposse. Outro para nelleseescreverem to $=\mid$ dos ostermos das determinaçoẽsda meza; Outro em que sefação ostermos, eassen $=\mid$ tos dosIrmaõs, eIrmãs, que entrarem de novo. Outro para sepassarem recibos ao $=\mid$ thezoureyro da quillo que para aIrmandade comprar, epagar. Outro emque sefa $=\mid$ raõ os assentos dos Irmaõs, eIrmãs, que falescerem, eporbaixo decada hum destes | assentos, passará oReverendo capellaõ certidaõ jurada das Missas, que disse, oufez di=| zer todosos Sabbados, Domingos, edias Santos da obrigação da capella, pelos Irmaõs vivos, e $=\mid$ defuntos da Irmandade, naforma declarada no capitulo 12, eemnenhi destes Livros | seescreverá outra cousa, mas doque aquillo para quesaõ destinados, para oque terá | cadahum por fora seu titullo.
\end{abstract}

Essa irmandade arrola seus livros em número de seis: 1. receita e despesa; 2. eleições e termos de posse; 3. termos da Mesa; 4. entrada de irmãos; 5. recibos ao tesoureiro; 6. irmãos falecidos. No capítulo $7^{\circ}$. de seu Compromisso há, entretanto, menção a um outro livro, o dos inventários, que não foi mencionado no rol de livros do capítulo $23^{\circ}$. Com ele totalizam-se sete tipos de livros, aos quais se acresce o Compromisso.

Com alguma variação no que diz respeito ao seu número e a sua nomenclatura, eram esses os livros geralmente possuídos pelas irmandades. A do Arcanjo São Miguel igualmente traz, em seu Compromisso, informações sobre os demais livros que ela possuía, que chegam ao número de seis. Porém, contrariamente ao que fez a Irmandade do Rosário, os livros são circunstancialmente mencionados ao longo de seu texto compromissal: 1 . o de termos (cap. $1^{\circ}$.); 2. o de receita e despesas; 3 . o de assento de irmãos; 4. o de eleições (cap. $5^{\circ}$.); 5 . o de certidão de missas (cap. $6^{\circ}$. e $35^{\circ}$.); 6. de tombo (cap. 50 $0^{\circ}$.). Já o Compromisso do Santíssimo do Ouro Preto discorre sobre seus livros em

9 Parece haver sinalização de mudança quanto a esse panorama. A programação do $55^{\circ}$. Seminário do GEL, realizado em 2007, traz resumo de comunicação individual na área de Filologia e Linguística Histórica, intitulada Estudo sobre Livro de Compromisso do século XIX, de autoria de Elizangela Nivardo Dias. 
dois capítulos, nos quais encontramos menção a quatro tipos: 1. eleições; 2. termos; 3. receitas e despesas (cap. $3^{\circ}$.); 4. assentos de irmãos (cap. $13^{\circ}$.). Embora nesse Compromisso não seja explicitado existência do livro de certidão de missas por intenção da alma de algum irmão falecido, seu capítulo $17^{\circ}$. reza que os sacerdotes deveriam passar "certidão jurada in verbo Sacerdotis" dos sufrágios realizados, "declarando onome do Irmaõ defunto". O livro em que essas certidões eram lançadas muito provavelmente se constituísse no sexto livro da irmandade, o de certidão de missas. ${ }^{10}$

Esses livros todos, ao contrário do Compromisso, relacionavam-se mais diretamente com as atividades do dia-a-dia de uma irmandade. Isso não quer, evidentemente, dizer que o Livro de Compromisso se desvinculasse do cotidiano confrarial. Muito pelo contrário, ele visava, por intermédio dos estatutos nele contidos, regulamentar as principais atividades das irmandades, sendo eventualmente consultado, como veremos adiante.

\section{Uma proposta para compreensão de Compromisso}

Como exposto, para que uma irmandade tivesse sua existência regulamentada, não bastava que devotos de certa invocação se reunissem, abrigassem-se em alguma igreja e ali erguessem o altar do santo de sua predileção para a prática devocional. Por disporem, simultaneamente, de um caráter religioso e outro temporal, jurídico, impunha-se a cada uma delas a redação de seu regulamento. Terminologicamente, esse regulamento recebia o nome de Livro de Compromisso ou simplesmente Compromisso.

$\mathrm{Na}$ tentativa de precisar como compromisso era entendido na época, recorremos a Bluteau. Seu Vocabulário portuguez, e latino, cuja publicação é coeva ao surgimento das irmandades na capitania das Minas, traz, em seu verbete compromisso, que essa "[...] he palavra antiga, que se deriva do verbo Comprir, \& na realidade parece, que Compromisso he um acto, em que muytos se obrigaõ a comprir as cousas, que assentaõ, \& prometem". Em seguida fornece uma acepção diversa, após a qual complementa:

\footnotetext{
Sem embargo desta diversa significação, fallando em Compromissos de Irmandades, \& outros semelhantes; já que Compromissum he palavra Latina, antes quizera eu usar della, do que cãçarme com algum impertinente periphrasis, ou cincunlocuçaõ. (1712, v.1, letra C, p.429)
}

10 Livros de Certidão de Missas dessa irmandade figuram no Inventário Analitico do Arquivo Eclesiástico da Paróquia de N.S. do Pilar de Ouro Preto. Há menção a livros desse gênero, períodos 1729 a 1785 e 1825; 1785 a 1843. (Ouro Preto, ESAF/Casa dos Contos, p.143) 
De acordo com Bluteau, o vocábulo compromisso provém, portanto, do verbo cumprir. os confrades de determinada irmandade seriam, então, obrigados a cumprir, ou seja, tornar efetivo o que era estatuído nesses Livros, que agrupavam sob a forma de capítulos não apenas os deveres, mas também os direitos dos irmãos filiados à irmandade. Essa vinculação entre irmandade $\mathrm{e}$ Compromisso torna a ser mencionada na mesma obra, agora no verbete $\mathrm{ir}$ mandade: "Sociedade de pessoas, que em virtude de hum compromisso, \& debaixo da invocaçaõ de algum Santo se obrigaõ a fazer alguns exercicios espirituaes.\&c." (1713, v.3, letra I, p.200)

A redação de Compromissos era prevista nas Constituiçoens Primeyras do Arcebispado da Babia (Vide, 1720), que regulamentaram, desde o início do século XVIII, a vida religiosa na América Portuguesa. Ao discorrer sobre as confrarias, Vide determina a remessa dos Compromissos ao Ordinário, para ajustes e aprovação, ou sua exibição aos visitadores eclesiásticos, quando de suas incursões pelo território diocesano:

867 POrque as Cõfrarias devem ser instituidas para serviço de Deos N. Senhor, honra, \& veneraçaõ dos Santos, \& se devem evitar nellas alguns abusos, \& juramentos indiscretos, que os Confrades, ou Irmãos põem em seus Estatutos, ou Cõpromissos, obrigando cõ elles a pensoens onerosas, \& talvez indecentes, de q Deos N. Senhor, \& os Santos naõ saõ servidos, convem muyto divertir estes inconvenientes. Por tanto mandamos, que das Confrarias deste nosso Arcebispado, que em sua creaçaõ foraõ erigidas por authoridade nossa, ou daqui em diante se quizerem erigir com a mesma authoridade, que as faz Ecclesiasticas, se remettaõ a Nòs os Estatutos, \& Compromissos, que quizerem de novo fazer, ou jà estiverem feytos, para se emendarem algis abusos, se nelles os houver, \& se passar licença in scriptis, para poderem usar delles.

868 E quanto às Confrarias que forem erigidas sem authoridade nossa, \& que saõ seculares, ordenamos, que os nossos Visitadores, nas Igrejas, em que ellas estaõ fundadas, \& em acto de Visita possaõ ver seus Estatutos, \& Cõpromissos, para que tendo na sobredita fórma alguns abusos, ou obrigaçoens menos decentes, \& pouco convenientes ao serviço de Deos, \& dos Santos, as façaõ emendar, (dandonos disso conta, sendo necessario,) ficãdo sempre as ditasConfrarias seculares, como d'antes erão, sem que pela dita diligẽcia possaõ os ditos Visitadores, \& seus Officiaes levar salario algum.

Além de (Livro de) Compromisso, encontra-se freqüentemente na documentação confrarial e em legislações eclesiásticas respeitantes ao funcionamento de irmandades o termo estatutos. Chega-se a verificar uma alternância de emprego entre esses vocábulos, que ora se dão a entender como sinônimos ora como sendo distintos um do outro. Nos parágrafos supracitados das 
Constituiçoens Primeyras já pudemos verificar isso: duas ocorrências no parágrafo 867 - "Estatutos, ou Cõpromissos" e "Estatutos, \& Compromissos" - e uma no 868, em que se repete a formulação aditiva "Estatutos, \& Cõpromissos" anteriormente observada. Isso nos leva a nos determos sobre esses vocábulos para melhor compreendê-los.

A irmandade de N.S. do Rosário da Paróquia do Pilar do Ouro Preto, em fólio preambular de seu novo Compromisso, menciona estatutos na passagem "fazendo no anno de 1715, os Irmaõs, que então serviaõ, estatutos, que aprovou ecomfirmou o Excelentíssimo eReverendíssimo Senhor Dom Frei Francisco de Saõ Hyeronimo, Bispo do Rio deIaneiro" (fól. 7r). Da mesma forma, diz que toda pessoa que entrasse para a confraria deveria "cumprir, e goardar, os estatutos da Irmandade" (cap. $1^{\circ}$.). Ainda, em petição do Juiz e irmãos, a Irmandade declara a perda do compromisso anterior e solicita confirmação daquele que apresenta, por ter acrescentado "alguns estatutos" (fól. 60r) à cópia do Livro de Compromisso perdido. Essas ocorrências apontam para uma diferenciação entre estatutos e compromisso, o que Geraldo José de Abranches, Provisor do Bispado de Mariana, parece corroborar no termo de encerramento que fez do mesmo Livro, em 21 de janeiro de 1751, aludindo a ele como "Libro doCompromisso, eEstatutos daIrmandade" (fol.73v).

Contrariamente, a Irmandade do Santíssimo, da mesma paróquia, no fólio preambular de seu novo Compromisso, serve-se do termo compromisso para referir-se àquilo a que a irmandade do Rosário designou como estatutos:

\footnotetext{
O Illustrissimo | Senhor Dom Francisco de São Hy- | eronimo antecessor de Vossa Illustrissi- | ma, foiservido no anno de 1712 mandar | passar Provizão deaprovação, e confirma- | ção de Compromisso á Irmandade do Santissimo Sacramento da | Igreja Parochial de Nossa Senhóra do Pillar de Villa Rica do ou- | ro preto, sendo aprimeyra, e mais antiga que nadita Freguesia féz | Compromisso […]. (fól. sem numeração ${ }^{11}$ )
}

Aliás, não apenas neste fólio inicial, mas ao longo de todo o Livro da Irmandade do Santíssimo, não há uma ocorrência sequer do vocábulo estatutos.

Já no Compromisso da Irmandade do Arcanjo São Miguel, da mesma paróquia, ${ }^{12}$ há ocorrências tanto de estatutos quanto de Compromisso. Em peti-

11 Esse fólio teve sua parte superior direita, no espaço em que se numerava e rubricava os fólios, rasgada. Pode-se ver, porém, parte da rubrica.

12 Em Minas, a devoção das almas teria se desenvolvido juntamente à de São Miguel (Campos, 1994, p.4). Embora não conste do frontispício desta irmandade a anexação das almas ao culto 
ção para obtenção de aprovação da reforma de seu Compromisso, seu emprego dá a entender serem estatutos partes integrantes do compromisso ("elles tendo feito oseu Compromiso, cujos e statutos"; "reformarem otal compromiço, comos estatutoz, ou cappituloz que juntoz [...] oferecem"), encontrando provável equivalência a capítulos ("estatutoz, ou cappituloz"):

Dizem o Juiz, emais Irmãos da | Meza daIrmandade das Almaz erecta, com authoridade doIllustríssimo | antecesor de Vossa Illustríssima na freguezia de Nosa senhora do Pillar de VillaRica | doouro preto, que elles tendo feito oseu Compromiso, cujos e statutos | foram approvadoz por Vossallustríssima como consta daprovizão daapprovaçam | econfirmaçam que seacha junta aomezmo compromiço, selhe faz deprezente | precizo, ecom o mezmo Compromico Velho [...]. (fól. 4r)

E, em outra passagem, presente em seu fólio preambular, em que essa mesma irmandade tece breves considerações históricas a seu respeito e procura justificar o porquê de se fazer novo Compromisso, consta que

passados annos cuida- | raõ os Irmaôs desta devotissima Irmandade | emfazer Compromisso, é estatutos paraserege- $\mid$ rem, dosquaes mandou o Illustríssimo Senhor Dom Francisco deSão Hyeronimo passar | provizão deerecção, e approvação noanno demilsetecentos e treze, é como o dito | Compromisso seacha emtermos desenão perceberem ascouzas determinadas | nelle, ejuntamente as Minas emgrande decadencia emrespeyto aotempo em | que se fórmaram os Estatutos á dita Jrmandade hè necessario fazer | a Jrmandade novos Estatutos para se reger, osquaes ordena na for- | maseguinte. (fól. 8r)

Aqui a Irmandade do Arcanjo São Miguel do Ouro Preto retoma o expediente apontado acima em passagem do Compromisso de N.S. do Rosário e das Constituiçoens Primeyras, em que deixa entender estatutos inicialmente como algo aditivo a compromisso (Compromisso, é $[=\mathrm{e}]$ estatutos). Em seguida, desfaz a presumida equivalência entre estatutos e capitulos há pouco aventada, ao registrar ser "necessario fazer | a Jrmandade novos Estatutos para se reger, osquaes ordena na for- $\mid$ maseguinte". Com isso aponta para o modo como os estatutos se apresentam ordenados, ou seja, agrupados sob a forma

de São Miguel (cf. Figura 1), a documentação presente no Compromisso alude em várias ocasiões a essa junção de invocações. Entre outras ocorrências, constatamos isso já no fólio preambular. Nele se lê que "A Irmandade do Ar- | chanjo S. Miguel, é Almas hê huã das | antigas desta Freguezia do ouro preto da- | Villa rica [...]" (fól. 8r) e na petição de confirmação do Compromisso ao bispo encontramos o mesmo expediente: "Dizem o Provedor, | e mais Irmaôs da Irmandade do Ar- | chanjo S.Miguel, é Almas cita na Fre| guezia deN. Snr.a do Pillar deVilla | rica de Ouro preto [...]" (fól. 62r). 
de capítulos, pois o primeiro dos 53 capítulos deste Livro encontra-se no fólio 9r, logo após o preâmbulo.

Podemos, então, chegar à conclusão de que o vocábulo estatutos - sempre usado no plural, assim como as Ordenações do Reino ${ }^{13}$ e as próprias Constituiçoens Primeyras - eram entendidos como o conjunto das disposições elaboradas pela irmandade, organizado sob forma de capítulos, e enviado à(s) autoridade(s) competente(s) para aprovação e confirmação, atos estes que produziam outros documentos. Já o compromisso - sempre mencionado no singular - corresponderia ao conjunto dos estatutos, acrescido das provisões de aprovação e confirmação, termo de abertura e encerramento do Livro, termos de encaminhamento, autos de justificação e outros tipos documentais gerados tanto interna quanto externamente ao espaço confrarial -, que legitimavam e/ou cerceavam os estatutos, e eram juntamente a eles encadernados.

Nesse sentido, o procurador da Mitra diocesana do Rio de Janeiro, ao determinar à Irmandade de São Miguel Arcanjo que "Ponhaõ os Suplicantes | em limpo os Capitulos | do compromisso, eencadernẽ | comelles a provizaõ | de erecçaõ que se acha | noCompromisso ve- | lho", dá-nos pista a respeito da forma como se compunha um Livro de Compromisso.

Se considerarmos um Livro de Compromisso iluminado, levando em conta os que conhecemos, podemos concebê-lo da seguinte forma:

1. Plano posterior da encadernação

2. Folha(s) de guarda

3. Termo de abertura

4. Fólio com iluminura do orago da irmandade

5. Frontispício em que se identifica o orago da irmandade, sua sede paroquial, o lugar onde se localiza e, em alguns Compromissos, o ano ou de sua ereção da irmandade ou da redação de seu Compromisso

6. Fólio preambular com breves considerações sobre a irmandade

7. Os estatutos ordenados em capítulos

8. Solicitação/Atestação de ereção e criação da Irmandade

9. Solicitação de aprovação eclesiástica

10. Solicitação de confirmação régia

11. Comentário sobre reforma de capítulos, emitido por autoridade competente.

13 Bluteau (1713, v.3, letra E, p.314) define estatuto como “Ordenaçaõ, Decreto". 
12. Despachos/Provisões das instâncias eclesiástica e/ou temporal, que geralmente incidem restrições ao compromisso apresentado

13. Outros gêneros documentais, como, por exemplo, disputas por precedência entre irmandades em procissões

14. Termo de encerramento

15. Folha de guarda

16. Plano posterior da encadernação

Um Livro de Compromisso com todos esses constituintes e nessa seqüencialidade configura-se num exemplo hipotético. A ordem de encadernação variava entre um Compromisso e outro, além do que nem todas as partes acima elencadas são uniformemente encontradas nos Compromissos existentes, com exceção dos itens 3, 5, 7, 12 e 14.

\section{Variação ortográfica nos documentos confrariais}

Os diferentes manuscritos confrariais acima arrolados configuram-se, em sua diversidade tipológica, em ricos documentos para o trabalho filológico. Entendemos poder dividi-los em dois grupos: do primeiro fariam parte os Compromissos; do segundo todos os demais livros de uma irmandade.

Esses manuscritos confrariais eram redigidos por diversos punhos, pois os ocupantes dos cargos das irmandades seriam, segundo as disposições dos Compromissos, renovados anualmente por eleição. Essa renovação constante de seus quadros, previstas nos Compromissos, espelhariam determinações emanadas da Igreja, que previam que "nenhiOfficial do anno passado será reeleyto, \& se o for naõ servirá se) lice)ça nossa, ou do nosso Provisor". ${ }^{14}$ Solicitava-se dos responsáveis pela escrita "que tenhaõ boa Letra, que tenhaõ inteligencia"15 "para escrever nos ditos Livros"16, o que não necessariamente verificamos nos documentos, pois a letra nem sempre é legível, apresentando certa dificuldade para sua edição.

14 Constituiçoens Primeyras do Arcebispado da Bahia. Livro IV, título LXII, "Da eleyçaõ dos Officiaes de cada Cõfraria, \& $\mathcal{Z}$ que cada anno dem conta com entrega, \& $\&$ das Missas, que se devem dizer nas ditas Confrarias.", n.872.

15 Cópia do Compromisso da Irmandade de N.S. do Rosário do Alto da Cruz da Freguesia de N.S. da Conceição de Antônio Dias do Ouro Preto, cap. $5^{\circ}$.

16 Compromisso da Irmandade de N.S. do Rosário do Ouro Preto, capítulo $6^{\circ}$. 


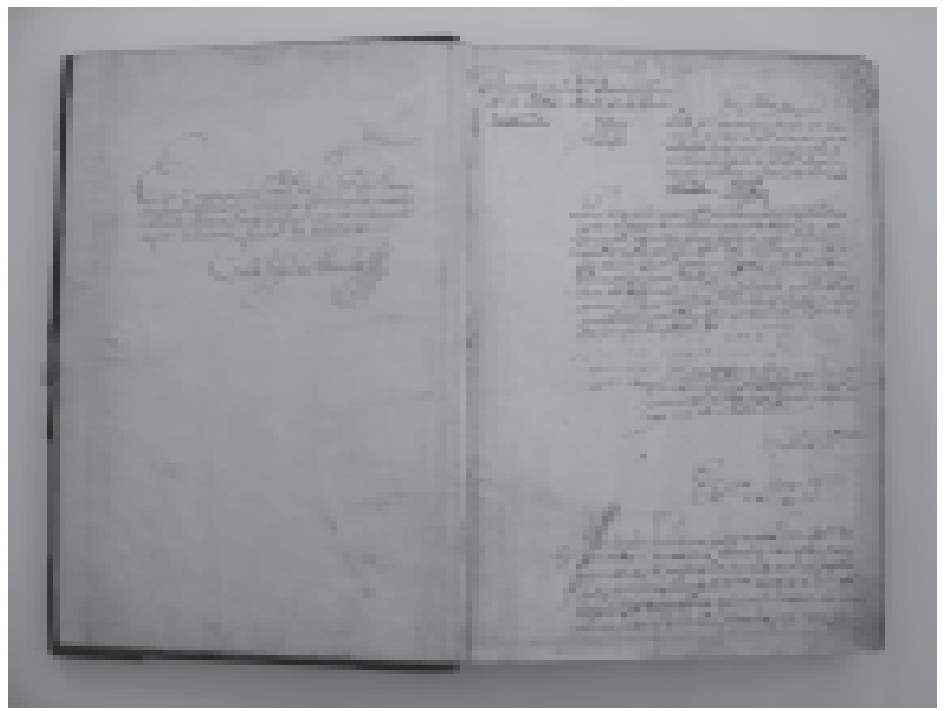

Figura 2 "Termo de abertura do Compromisso da Irmandade de N.S. do Rosário dos Pretos da paróquia de N.S. do Pilar do Ouro Preto (verso da folha de guarda) e encaminhamento ao bispo, com parecer do provisor do bispado para "comfirmaçaõ dos Cappitulos do | prezente Compromiso" (fól. 1r).

Tais manuscritos se configuram em bom exemplo das contradições ortográficas e das idiossincrasias que caracterizaram a escrita do Setecentos, a ponto de despertarem a atenção até mesmo de pessoas não inseridas no campo dos estudos filológicos. O musicólogo Francisco Curt Lange (1981), por exemplo, que realizou pesquisa em arquivos confrariais mineiros em busca de dados inerentes ao seu domínio, surpreendeu-se com a variação ortográfica com que o instrumento musical denominado charamela e palavras derivadas foram grafadas no Livro de Receita e Despesa da Irmandade de Nossa Senhora do Rosário dos Pretos do Alto da Cruz do Padre Faria, de Ouro Preto. Elaborou a seguinte listagem:

$\begin{array}{lll}\begin{array}{l}\text { Chamarellas } \\ \text { Charomellas } \\ \text { Chormelleyros }\end{array} & \begin{array}{l}\text { Charamelleyros } \\ \text { Charomelleyros }\end{array} & \begin{array}{l}\text { Charamelleiros } \\ \text { Charomelleiros }\end{array} \\ \text { Choromelleyros } & & \text { Choromelleiros } \\ \text { Choromillyros } & \text { Coromileyros } & \end{array}$


Chromelleyros

Churomellas

Chromeleyros

Churomelles

Coromellas

Xorameleyros

Xoramelles

Xoromellos

Escapando a essa abundância de punhos que intervinham nas variadas modalidades de códices confrarias e que propiciavam uma extensa variação ortográfica, encontram-se os estatutos presentes nos Livros de Compromisso. A uniformidade e o cuidado caligráficos neles presentes apontam para um único punho na redação de seus estatutos, o que, no entanto, não significa que haja uniformidade ortográfica. Como exemplo, encontramos no Compromisso de N.S. do Rosário dos Pretos do Ouro Preto as seguintes ocorrências: procissão (cap. $2^{\circ}$.), porcissão (cap. $4^{\circ}$. e $17^{\circ}$.), porcissães (cap. $5^{\circ}$.), porcisões (cap. $11^{\circ}$.), porcissoẽs (cap. $12^{\circ}$. e $13^{\circ}$.); nasção (cap. $1^{\circ}$.), nassão (cap. $2^{\circ}$.); determinar (cap. $4^{\circ}, 5^{\circ}$., $9^{\circ}$. e $10^{\circ}$.), detreminar (cap. $8^{\circ}$.). Embora as ocorrências de fluidez ortográfica sejam reduzidas quando comparadas aos demais livros de irmandades, os estatutos atestam que a deriva ortográfica característica da escrita do Setecentos não ocorria somente entre um copista ou autor material e outro, mas ao longo do texto do mesmo copista ou autor material. Percebe-se, entre os letrados da época, oscilação entre princípios etimologizantes, como em vocábulos como thezoureyro, e oralizante, como nos exemplos acima. Essa doutrina, a de se escrever a língua portuguesa do mesmo modo como é pronunciada, parece ter sido corrente na época, uma vez que Figueiredo atribui o seguinte título ao primeiro tratado de sua obra: " $\mathrm{Da}$ instrucc,am [sic] para ensinar a ler o Idioma Portuguez com brevidade, e sufficiencia para se escrever, assim como se pronuncia." (1722, p.1). E isso independentemente dos predicativos intelectuais de cada um, uma vez que Verney (1949, p.95) salientou que tal inconstância na ortografia ocorresse ainda entre doutos conhecedores da língua, ao mencionar "que o Bluteau é inconstante na Ortografia".

\section{Guarda e leitura de documentos confrariais}

Entre os cargos existentes numa irmandade, o escrivão e o tesoureiro eram os que mais se ligavam às lides com os livros. Ao escrivão cabia zelar pelos livros de sua irmandade: ${ }^{17}$ caso a irmandade não dispusesse de arquivo

17 Cf. capítulos $6^{\circ}$ do Compromisso do Rosário, capítulos $1^{\circ}$. e $5^{\circ}$. do de São Miguel e capítulo $3^{\circ}$. do Livro do Santíssimo. 
para guardá-los, ${ }^{18}$ o escrivão deveria tê-los “em seu poder", segundo expressão corrente nos Compromissos. A considerar pela passagem do capítulo $1^{\circ}$ do Compromisso do Arcanjo São Miguel, "o ter os livros em seu poder" implicaria guardá-los em sua casa, dado que, nessa irmandade, quando uma pessoa se interessasse em se associar a ela, deveria fazer petição à mesa ou ir "acaza do Escrivão que estiver servindo para lhefazer termo no Livro delles". Entendemos que isso se desse não apenas por falta de arquivo para acomodação de seus livros, mas também para comodidade da pessoa encarregada de neles lançar assentos, uma vez tendo-os junto de si, em sua morada. Contudo, segundo a tipologia do livro, era sob a responsabilidade do tesoureiro da irmandade que alguns deles ficavam. Nesse sentido, a Irmandade de N.S. do Rosário do Ouro Preto consignou, em seu capítulo $6^{\circ}$, que

\begin{abstract}
A obrigação do Escrivao, hé ter em= $\mid$ seu poder, todos osLivros, epapeis daIrmandade, naõ tendo esta archivo em que sego $=\mid$ ardem, excépto aquelles dascertidoẽs das Missas, eRecibos, por que estaraõ empoder | do thezoureyro, para nelles passar ascertidoẽs, erecibos, áquellas pessoas, aquem pa $=\mid$ gar, enosmais naõ poderá escrever outra pessoa alguã mais que oditoEscrivaõ, | só no cazo, que este esteja impedido, equando asim suceda, ameza elejerá pessoa | inteligente, para escrever nos ditos Livros [...].
\end{abstract}

Esses livros todos pareciam circular bastante, levando em conta que os cargos confrariais eram exercidos em forma de rodízio, por eleição anual. Os livros passariam então, com certa freqüência, de mãos em mãos, segundo quem estivesse responsável por eles no momento. De acordo com o capítulo $3^{\circ}$ do Compromisso do Santíssimo, aos responsáveis eles seriam "entregues comás de- | claraçoens dequantos, e o paraqueservem":

O Escrivam tem por- | obrigação ter emseu poder todos os Livros da | Irmandade, que lheseràm entregues comás de- | claraçoens dequantos, e o paraqueservem, e te- | rà todo ocuidado delançar nelles as Eleyções, | fazer termos aos Irmaôs, eaomais necessario, | e receitas, edespezas ao Thezoureyro, tudo com | tanta deligencia, ecuidado, que sirva deestimulo aosmais [...].

Aqui encontramos, novamente, em terras americanas, prática semelhante à ibérica, dado que López Gutiérrez \& Rodríguez Mateos apontam que, devido à falta de um espaço físico destinado à função de arquivo das irmandades, "la documentación de la Hermandad quedaba depositada em las casas del Hermano Mayor, Secretario o Mayordomo" (1993, p.34).

18 Cf. capítulos $6^{\circ}$ do Compromisso do Rosário e $5^{\circ}$. de São Miguel. 
Sendo o Compromisso o códice que continha os estatutos pelos quais cada irmandade se regia, equivalendo à sua lei, ${ }^{19}$ seria regularmente consultado e lido. Para conhecimento das normas nele prescritas, sessões de leitura deviam-se realizar, em ocasiões como a de entrada de irmão, pois a lei da confraria "deve ser conhecida e seguida por todos os membros que antes da admissão prestam juramento" (Scarano, 1975, p.29) e, especialmente, logo após a posse das mesas administrativas das irmandades, para conhecimento, por parte dos oficiais eleitos, de suas atribuições no sodalício. Nesse sentido, a Irmandade de São Miguel e Almas do Purgatório, de São Caetano Ribeirão Abaixo estabelece, em seu capítulo $12^{\circ}$, que haveria na

irmandade todos osannos quatro juntas, em: | as quaes asistirão todos os officiaes, \&irmaõs de meza que naque | le tempo servirem, perante os quaes mandarâ oIuisler este com | promisso, \&lhesproporâ oque sedeve tratar nesta irmandade, \&a $\mid$ cada hum depersi mandarâ votar [...].

Do mesmo modo, cabia ao escrivão da Irmandade do Santíssimo Sacramento de Mariana "abrir o | Compromisso em todas as Mezas, eler oCapitulo doparticular emque querem tra $\mid$ tar, eeste estarâ fexado nacasa doConsistorio" (cap. $42^{\circ}$.). Essa passagem informa-nos ainda o local onde a irmandade guardaria o Compromisso: no consistório, ou seja, na sala de reunião da irmandade. Essa obrigação do escrivão - a de ler trechos do Compromisso durante as mesas (= reuniões administrativas) da irmandade é reafirmada em seguida, quando se consigna que ao procurador caberia requerer "nas Mezas ao Escrivão leya o Capitulo do Compromisso, que | pertencer ámateria deque tratão" (cap. $44^{\circ}$.).

Há uma questão que se observa nos Compromissos que entendemos merecer comentário: a forma como se entendia publicação na época em que eles foram redigidos. As irmandades realizavam eleições anuais para renovação dos ocupantes de seus cargos administrativos, em datas significativas do calendário cristão ou da irmandade,$^{20}$ e alguns Compromissos detêm-se minudentemente sobre elas, ressaltando o ambiente secreto em que deveriam

19 A Irmandade de N.S. do Rosário dos Pretos do Alto da Cruz assim se refere ao seu Compromisso em seu fólio preambular: "Este Compromisso he Ley invio $=\mid$ lavel, aque sesugeitaõ aqueles Catholicos, que se | querem alistar nos Livros desta Irmandade [...]”.

20 As Constituiçoens Primeyras do Arcebispado da Babia ordenam "que em cada hi anno, atè quinze dias depois da festa principal da Canfraria, em hum Domingo, ou dia Santo se elejaõ novos Officiaes, sendo presentes os que acabàrão de o ser". Livro IV, título LXII, "Da eleyçaõ dos Officiaes de cada Cõfraria, \& que cada anno dem conta com entrega,\& das Missas, que se devem dizer nas ditas Confrarias.", n. 872. 
ocorrer. Sua apuração dar-se-ia igualmente de modo sigiloso, para divulgação dos nomes dos novos oficiais em momento determinado no Compromisso. O Compromisso da Irmandade do Santíssimo do Ouro Preto estabelece, em seu capítulo $10^{\circ}$, que o pároco "farà publicar namanhaâ dodia | de Paschoa" o resultado da eleição para os cargos administrativos de sua irmandade, sem muito detalhamento; já o da Irmandade do Rosário, da mesma paróquia, é esclarecedor quanto à forma de publicação: ao estabelecer em seu capítulo $16^{\circ}$ que "oIuis decada festa entregará asua eLeição ao Reverendo Pregador, para do Pulpito apublicar ao povo no dia dasua festa", revela o caráter oral da publicação. Isso também se verifica no capítulo $13^{\circ}$ do Compromisso do Arcanjo São Miguel, segundo o qual após o final da eleição e

pòsta apauta em limpo, é | assinada pelo Reverendo Vigário sedarà ao Reverendo | Pregador para apublicar do Pulpito no dia | dafesta do Archanjo S. Miguel, e assim que publicada fór, o Escrivam | farà avizo por escrito aos novovos [sic] officiaes, como Irmâos, convocan- | do-os logo ahuns, éoutros para odia determinado da emtrega como fica $\mid$ dito no Capitulo $5^{\circ}$.

Essa passagem, aliás, não só reforça que a publicação consistia em um ato de leitura em voz alta, como também lhe impõe um aspecto de oficialização, de reconhecimento e de encerramento do processo eleitoral, uma vez que, apenas após a publicação, os novos ocupantes dos cargos seriam convocados a assumi-los.

\section{Cópias e traslados dos Compromissos}

Vimos anteriormente que, ao reformarem seus Compromissos, as irmandades, dependendo do que alegassem em relação ao Livro anterior, explicitavam a existência de uma sua cópia que, com ajustes e acrescentamentos, resultava no Compromisso reformado. A irmandade do Rosário do Ouro Preto, ao apresentar seu novo Compromisso e declarar ter perdido o anterior, justifica não ter ficado sem sua lei no intervalo de tempo entre a perda do Livro velho e a redação do novo, pois "the aqui segouernaraõ | com acopia que delle ficou eacrescentaraõ algu | mas clauzulas no dito Comprimisso" (fól. 1r). Uma outra Irmandade de N.S. do Rosário, ereta na mesma Vila Rica, também dispunha de uma "Copia do | Compromisso da | Irmandade de Nossa Senhora do Rozario dos | Pretos, denominada do Alto da Cruz da | Freguesia de Nossa Senhora da Conceição de An | tonio Dias de Villa Rica do Ouro preto". Já os confrades da "Irmandade | do Patriarcha S. Joze dos bem Cazados | Erigida pelos Pardos de Villa Rica no | Anno de 1730", antes de 
enviarem seu Compromisso à metrópole para confirmação régia, procederam a uma cópia dele, em cujo fólio frontispicial consta

Translado authentico do | Compromisso daIrmandade do Patriarca São | Jozé Ereta na Freguezia de Nossa Senhora do Pillar do | Ouro preto o qual proprio foi remetido a Meza | daConciencia eordens da Cidade de Lisboa porOr- | dem deSua Magestade fidelicima que | Deos goarde.

Os irmãos de São José precaveram-se e elaboraram um translado para que, durante o tempo em que seu Compromisso estivesse tramitando pela sinuosa burocracia metropolitana, não ficassem sem estatutos com que se regessem. Segundo Boschi (1986, p.119), devido à distância entre a Capitania das Minas e a Metrópole, a morosidade do processo era previsível, razão por que "uma vez remetido o compromisso para Lisboa, as irmandades já o tomassem como texto definitivo". De modo semelhante, os irmãos do Santíssimo de Mariana, em razão de serem "obrigados aobedecer aos nossos Parochos como suas ove- | lhas", determinavam que os "Parochos tenhão emseo poder otresla- | do delles [dos estatutos], para que como Fiscal das Irmandades fação observar tudo oque nellez | contem" (cap. 46\%).

Os Compromissos não eram redigidos para circulação pública, nem para posse pessoal de cada um dos irmãos, mas sim para manuseio restrito ao interior de ambientes institucionalizados ou entre alguns dos confrades da irmandade. Tais reproduções, fossem na forma de cópia ou traslado, deveriam ser feitas com vistas a atender uma finalidade prática ou legal da irmandade - ter uma versão sempre às vistas do Livro enviado ao reino -, ou para disponibilizar acesso direto e constante do Compromisso a pessoas envolvidas em sua administração, poupando assim manuseio da versão iluminada de seu Livro, para as irmandades que dela dispusessem.

\section{Temáticas dos compromissos e provisões sobre eles}

Assim como os livros que uma irmandade possuía apresentavam certa regularidade, as disposições expressas em seus Livros de Compromisso mantinham temáticas recorrentes, embora a minudência com que elas eram tratadas por cada irmandade variasse de uma para outra, mesmo que elas tivessem como orago a mesma devoção. Assim sendo, não havia, por assim dizer, o Compromisso-padrão das irmandades eretas sob um orago comum. Cada uma delas redigia seu próprio Livro. Em Vila Rica, por exemplo, havia duas irmandades do Santíssimo Sacramento e duas de N.S. do Rosário, cada uma com Compromisso próprio. 
As temáticas abordadas nos Compromissos parecem repetir-se de forma bastante consistente em todos eles, divididas em um número de capítulos que varia de Compromisso para Compromisso. ${ }^{21}$ Fazendo uma breve apresentação, as principais tratam da festa do padroeiro: quando e como celebrá-la; da eleição de oficiais para os cargos; do valor das esmolas dos oficiais; da prestação de contas aos novos oficiais pelos anteriores e informação de suas atribuições; da condição moral para se entrar na irmandade; valor da entrada e do anual; da procissão e ofício pelas almas dos irmãos; das pessoas (mulheres, negros, pardos...) que poderão ou não participar da irmandade; da assistência a irmãos doentes; das sepulturas no interior do templo; de questões relacionadas à morte e ao sepultamento: anúncio da morte, enterro e sufrágios das almas dos irmãos: quantos e quando rezá-los; das missas e procissões; dos donativos/pagamentos diversos e especificamente ao vigário; de como contratar capelão; de capela de missas por intenção de irmãos vivos e falecidos; do recebimento das esmolas para missas pelas almas e seu lançamento em livro competente; das qualidades do tesoureiro; das juntas deliberativas anuais em que se lerá o Compromisso; forma de votação; multas para os oficiais e irmãos de mesa ausentes nessas ocasiões; da conciliação de irmãos em litígio e expulsão daqueles que se recusassem a isso; das atribuições do tesoureiro e penalidade caso infrinja alguma atribuição; da existência de livros para registro das atividades da irmandade; livros em poder do escrivão e sua responsabilidade sobre eles; da função dos oficiais em atos públicos da irmandade; da renovação da mesa administrativa; da obrigatoriedade em guardar o que o Compromisso prescreve; do auxílio em caso de extrema pobreza e, às vezes, perseguição de justiça; do comprometimento em se cumprir o estatúdo no Compromisso, sem inová-lo sem licença para tal.

Entre as prescrições estatutárias e seu fiel cumprimento parece ter havido um passo muito largo. Talvez seja por isso que Scarano (1975, p.37) questione o efetivo cumprimento do quesito associado à conduta do confrade, ao concluir que as "confrarias chamam à ordem os associados de mau procedimento e estabelecem regras bastante estritas de moralidade. Entretanto, dificilmente tais regras poderiam ser mantidas em terras mineiras daquele período".

Enfim, após ser redigido, o Compromisso submetia-se às vistas do bispo ou de algum visitador diocesano. Como deixaram claro os parágrafos 867

21 Os Compromissos seguintes, de irmandades filiais à paróquia de N.S. do Pilar do Ouro Preto, apresentam o seguinte número de capítulos: o de N.S. do Rosário dos Pretos 24 capítulos; o do Santíssimo, 34 capítulos; o do Arcanjo São Miguel, 53. 
e 868 das Constituicoens, a autoridade eclesiástica detinha poder para "se emendarem algis abusos, se nelles os houver" e passar licença por escrito para se fazer uso dele. A essa forma de controle eclesiástico sobrepôs-se outra, de âmbito civil, na segunda metade do século XVIII, quando o primeiro-ministro de D. José I, Marquês de Pombal, determinou que os Compromissos fossem submetidos à confirmação da Mesa da Consciência e Ordens - tribunal régio para os negócios da Fé -, que passou a controlar efetivamente as irmandades (Boschi, 1986, p.114-6). Os Livros de Compromisso eram, em suma, um tipo de manuscrito supervisionado tanto pelo poder religioso quanto pelo temporal. Uma vez aprovados, legitimavam o nascimento do círculo confrarial ou o tirava da bastardia, eram, enfim, sua validação institucional, o documento que oficializava seu funcionamento. É o que relata Boschi, ao afirmar que

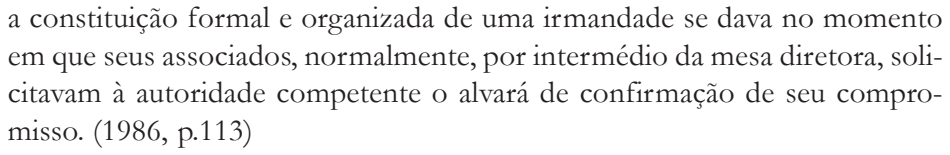
em que seus associados, normalmente, por intermédio da mesa diretora, solicitavam à autoridade competente o alvará de confirmação de seu compromisso. (1986, p.113)

Essas autoridades, fossem de uma instância ou de outra, ao aprovarem os Compromissos, anexavam a eles provisões em que, de ordinário, impunham alguma restrição a partes de seu conteúdo. Essas instâncias tinham, porém, alvos diferentes. Quando as aprovações aos Compromissos mineiros eram feitas por visitadores oriundos predominantemente do Rio de Janeiro, as restrições impostas eram primordialmente de caráter espiritual e religioso, derrogando "alguns abusos, ou obrigaçoens menos decentes, \& pouco convenientes ao serviço de Deos, \& dos Santos", como vimos acima, em citação das Constituicoens Primeyras, e secundariamente de ordem administrativa. Quando a interveniência temporal se impôs - agudizando-se progressivamente sob os reinados de D. Maria I e D. João VI -, as restrições emanadas dessa instância recaíram sobre aspectos de ordem social, econômica e administrativa. O cotejo das provisões com os estatutos dos compromissos explicam interpolações e tachados presentes em parte deles. 


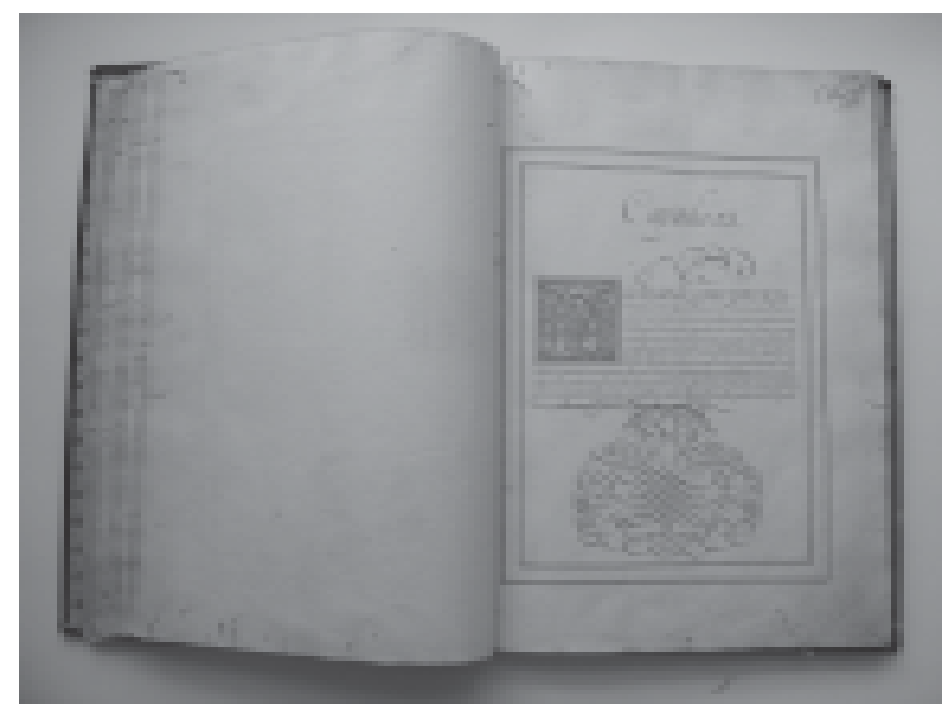

Figura 3 "Capítulo $13^{\circ}$ do Compromisso do Santíssimo Sacramento da paróquia de N.S. do Pilar do Ouro Preto, em que se observam tachado e acréscimo ao final do texto.

A coexistência dessas alçadas - a religiosa e a temporal - exercendo poder de ratificação do conteúdo dos Compromissos não foi complementar nem pacífica (Boschi, 1986, p.112-39). Muito pelo contrário. Nas provisões régias o atrito entre elas torna-se patente, pois nelas se firmava a nulidade da provisão eclesiástica aos olhos reais. Nesse sentido, a provisão emanada por D. José I em 29 de julho de 1773 sobre o Compromisso da Irmandade de N.S. do Rosário dos Pretos do Ouro Preto, mais de 20 anos depois de obtenção da provisão do bispado de Mariana, indulgencia os confrades por

\footnotetext{
terem por | Ignorancia confirmado oseu Compromiço pello Ordinário | dodito Bispado, cuja incompetencia reconhecendo agora | e a jurisdiçaõ, que adita Ordem compete, ofereciaõ na minha | Real presença odito compromiço pedindo me fosse servido com | firmar lho. (fól. 20v)
}

A Irmandade do Arcanjo São Miguel submeteu seu Compromisso, datado de meados de 1730 , às vistas reais e, segundo provisão régia de 1777 , teria conseguido, com isso, "Sannar | Anullidade comque adita Irmandade tinha sido | Erecta revalidando lheareferida Licença”" (fól. 67r), e D. Maria I assentou, em sua provisão em favor dos irmãos do Santíssimo Sacramento do Ouro Preto, ser "Servida declarár nullaaProvizaõ | de confirmaçaõ folhas trintae nove, concedida in= | competentemente, pello referidoBispo" (fól. 40r). 
A animosidade entre reis e bispos exprime-se, nos Compromissos, sem meias palavras.

\section{Conclusão}

Após discorrer sobre a origem das irmandades religiosas leigas e, particularmente, sobre seu papel nas Minas setecentistas, o presente artigo procurou fazer um levantamento da tipologia de livros confrariais existentes no interior dessas associações, com o propósito de focar o olhar sobre um deles, o Livro de Compromisso. Centrando-se nesse tipo documental, tratou de seu papel junto às irmandades e de agentes intervenientes em sua estrutura durante sua tramitação nas instituições regulamentadoras.

Após analisar ocorrências dos termos estatutos e compromisso, não apenas nos Livros analisados, mas também em autores coetâneos à sua elaboração, conclui ser o conjunto dos estatutos, ordenados sob a forma de capítulos, um dos constituintes do Compromisso, unidade maior que agrega outros documentos atinentes aos estatutos. $\mathrm{O}$ fato de os estatutos serem vazados por um único punho não os isentava da variação ortográfica, atributo do tempo em que foram escritos, embora pareça se verificar neles variação menor do que aquela encontrada em outros livros, que registravam atividades voltadas ao cotidiano confrarial e cujos responsáveis por sua guarda e escrita - geralmente o escrivão e o tesoureiro "eram rotativos. Os Compromissos nos fornecem, também, indicativos de que a forma verbal de publicação era prática vigente na época, e que eles eram reproduzidos sob a forma de cópia e traslado. As temáticas tratadas pelos estatutos dos Compromissos apresentavam homogeneidade, por essa razão procurou-se elencá-las resumidamente para, finalmente, tratar das coerções a que os Compromissos estavam sujeitos ao passar pelas vistas de superior eclesiástico e do soberano português, que corporificavam instâncias de ânimo tempestuoso uma frente à outra. Com isso tentou apontar para a relevância de um material a ser estudado não apenas pela filologia, mas também por ciências afins, como a paleografia, a codicologia e a diplomática.

\section{Bibliografia}

AGUIAR. M. M. de. (1993) Vila Rica dos confrades: a sociabilidade confrarial entre negros e mulatos no século XVIII. 351 f. São Paulo. Dissertação (Mestrado em História) -- Faculdade de Filosofia, Letras e Ciências Humanas, Universidade de São Paulo.

BOSCHI. (1986) Os leigos e o poder. São Paulo: Ática. 
. (1987) As Diretrizes Metropolitanas, a Realidade Colonial e as Irmandades Mineiras. Revista Brasileira de Estudos Politicos, 65, p.131-51, jul. 1987.

BLUTEAU, R. (1712-17210Vocabulario portuguez, e latino ... Coimbra: Collegio das Artes da Companhia de JESU [1712-1721].

CAMPOS, A. A. (1994) A terceira devoção do Setecentos mineiro: o culto a São Miguel e Almas. São Paulo. Tese (Doutorado em História Social)- Faculdade de Filosofia, Letras e Ciências Humanas, Universidade de São Paulo.

CAMPOS, A. A. (org.) (2005) Manoel da Costa Ataíde: aspectos históricos, estilísticos, iconográficos e técnicos. Belo Horizonte: C/Arte.

DIAS, E. N. (2007) Estudo sobre Livro de Compromisso do século XIX. Disponível em <http:// gel.org.br/3sem-2007/simposios/simp_00282.html>. Acesso em 25 de novembro de 2007. DUBY, G. (1999) Ano 1000 ano 2000: na pista de nossos medos. São Paulo: Editora da UNESP. ESTEVES, S. M. P. (1987) As iluminuras dos Compromissos de irmandades e ordens terceiras da arquidiocese de Mariana - 1717/1818. Monografia. 154f. (Especialização em Cultura e Arte Barroca) - Instituto de Filosofia, Artes e Cultura, Universidade Federal de Ouro Preto.

FIGUEIREDO, M. de A. de (1722) Nova escola para aprender a ler, escrever, e contar. Lisboa: Oficina de Bernardo da Costa de Carvalho. Tratado I.

HOLANDA, S. B. (1979) A cristandade durante a primeira época colonial. In: (coord.).

História da Igreja no Brasil. Petrópolis: Vozes, t.2, p.243-411.

HOORNAERT, E. (1974) Formação do catolicismo brasileiro 1550-1800. Petrópolis: Vozes.

LANGE, F.C. (1981) História da música nas irmandades de Vila Rica: Freguesia de Nossa Senhora da Conceição de Antônio Dias. Belo Horizonte: Conselho Estadual de Cultura de Minas Gerais, v.V.

LÓPEZ GUTIÉRREZ, A. J. \& RODRÍGUES MATEOS, J. (1993) Los archivos de las hermandades religiosas. Sevelha: G.E.A.

MARIANA. ARQUIVO ECLESIÁSTICO DA ARQUIDIOCESE DE MARIANA. (1713/ 1735) Compromisso da Irmandade do Sanctîssîmo Sacramento da Freguezîa de N. Senhorada Conceiçaõ da Vîlla do Ribeiraõ deN. S. do Carmo.

MEGALE, H. et al. (2001) Normas para transcrição de documentos manuscritos para a história do português no Brasil. In: SILVA, R. V. M. e. (org.). Para a história do português brasileiro. São Paulo: Humanitas / FFLCH/USP: Fapesp, v.II. t.II. p.553-555.

MONTANHEIRO, F. C. (2002) Vožes silentes em Compromissos mineiros do século XVIII: espaços discursivos do sujeito negro em irmandades religiosas leigas. Araraquara. Dissertação (Mestrado em Lingüística e Língua Portuguesa) - Faculdade de Ciências e Letras, UNESP.

(2007) Livros de Compromisso: práticas em torno de um fazer livresco nas Minas setecentistas. Araraquara. Tese (Doutorado em Lingüística e Língua Portuguesa) - Faculdade de Ciências e Letras, UNESP.

OLIVEIRA, Dom O. de. (1964) Os dízimos eclesiásticos do Brasil nos períodos da Colônia e do Império. Belo Horizonte: Imprensa da Universidade de Minas Gerais.

OURO PRETO. ARQUIVO CASA DOS CONTOS. (1730) Translado authentico do Compromisso daIrmandade Irmandade do Patriarcha S. Joze dos bem Cazados Erigida pelos Pardos de Villa Rica no Anno de 1730.

(1733-1788) Cópia do Compromisso da Irmandade de N. Senhora do Rozario dos Pretos, denominada do Alto da Cruz da Freg. ${ }^{a}$ de N. Senhora da Conceição de Antonio Dias de V. ${ }^{a}$ Rica do Ouro preto. 
OURO PRETO. ARQUIVO ECLESIÁSTICO DA PARÓQUIA DE N.S. DO PILAR. (1738) Compromisso da Jrmandade do S. ${ }^{\text {mo }}$ Sacram. ${ }^{\text {to }}$ sita na Matriz de N. S. do Pillar de Ouro Preto. OURO PRETO. ARQUIVO ECLESIÁSTICO DA PARÓQUIA DE N.S. DO PILAR. (1750) Compromiso da Irmandade, de N. S. ${ }^{\text {ra }}$ doRosario, dos Pretos nasva capela filial damatris. de

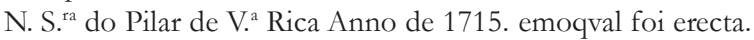

OURO PRETO. ARQUIVO ECLESIÁSTICO DA PARÓQUIA DE N.S. DO PILAR. (1735) Compromiso da J' rmandade do Archanîo S. Miguel cita na Freguezia de N.S. do Pîllar de Villa Ríca do Ouro Preto.

OURO PRETO. ESAF/CENTRO DE ESTUDOS DO CICLO DO OURO/CASA DOS CONTOS. (2000) Inventário Analítico do Arquivo Eclesiástico da Paróquia de N.S. do Pilar de Ouro Preto.

OURO PRETO. MUSEU DA INCONFIDÊNCIA. (1722) Compromisso daÎrmandade do S. S. Mîguel, e Almas doPurgatorîo da Freguezia de S.Caetano Ribeirãoabaixo Anno.M.DCC.XXII.

PERUCCI, S. M. (1994) Iluminuras nos Livros de Compromisso de Irmandades e Ordens Terceiras de Ouro Preto e Mariana: uma Abordagem. Revista do IAC, Ouro Preto, 1, p. 49-60. REIS, J. J. (1991) A morte é uma festa. São Paulo: Companhia das Letras.

SALLES, F.T. (1963) Associações religiosas no ciclo do ouro. Belo Horizonte: Imprensa da UFMG. SCARANO, J. (1975) Devoção e escravidão: a irmandade de Nossa Senhora do Rosário dos Pretos no Distrito Diamantino no Século XVIII. São Paulo: Conselho Estadual de Cultura. (Brasiliana, 357).

SILVA Y VERÁSTEGUI, S. La miniatura medieval en Navarra. Pamplona: Gobierno de Navarra, 1988.

SOARES, M. de C. (2000) Devotos da cor. Rio de Janeiro: Civilização Brasileira.

SOUZA, M. de M. e. (2002) Reis negros no Brasil escravista: história da festa de coroação de Rei Congo. Belo Horizonte: Editora UFMG.

TACHY, A. (1898) Traité des confréries et des cuvres pies. 2. ed. Langres: Rallet-Ridéaud.

VERNEY, L. A. (1949) Plano dos estudos de língua portuguesa. Verdadeiro método de estudar. Lisboa: Livraria Sá da Costa, p.34-134.

VIDE, S. M. da. (1720) Constituiçoens Primeyras do Arcebispado da Babia [...]. s.l.: Real Collegio das Artes da Comp. de JESUS.

ABSTRACT: This paper aims to present some of the Livros de Compromisso and other books generated by lay catholic brotherhoods in the 18th Century in the cities of Ouro Preto and Mariana, Minas Gerais State, Brazil, nowadays belonging to the Arquivo Eclesiástico da Paróquia de N.S. do Pilar de Ouro Preto, the Museu da Inconfidência, the Arquivo Casa dos Contos and the Arquivo Eclesiástico da Arquidiocese de Mariana. The Compromisso is a written commitment that allows the brotherhood to exist. These brotherhoods, known in Portuguese as irmandades, were officially recognized institutions by the religious and royal instances by means of these books. Their activities were registered in a variety of different books with specific purpose that provide us with an important heritage of manuscript documentation still little studied in the philologic domain. A brief historical view on the institution brotherhood is presented and extracts from different Compromissos are analysed in order to emphasize the 
singularity of this document. A proposal to understand the role and the structure of this book is produced. Some recurrent aspects on the Compromissos are singled out, examined and exemplified: the spelling variation, the ownership and the occasions when these books ought to be read, the existence of different kinds of written reproduction of the same book, the ordinary thematic prescriptions and the provisions made by ecclesiastical and/or royal power.This paper aims to present some of the Livros de Compromisso and other books generated by lay catholic brotherhoods in the 18th Century in the cities of Ouro Preto and Mariana, State of Minas Gerais, Brazil, nowadays belonging to the Arquivo Eclesiástico da Paróquia de N.S. do Pilar de Ouro Preto, the Museu da Inconfidência, the Arquivo Casa dos Contos and the Arquivo Eclesiástico da Arquidiocese de Mariana. The Compromisso is a written commitement that allows the brotherhood to exist. These brotherhoods, known in Portuguese as irmandades, were officially recognized institutions by the religious and royal instances by means of these books. Their activities were registered in a variety of different books with specific purpose that bequeathed us with an important heritage of manuscript documentation still little studied in the philologic domain. A brief historical view on the institution brotherhood is presented and extracts from different Compromissos are analysed in order to emphasize the singularity of this document. A proposal to understand the role and the structure of this book is produced. Some recurrent aspects on the Compromissos are singled out, examined and exemplified: the spelling variation, the ownership and the occasions when these books ought to be read, the existence of different kinds of written reproduction of the same book, the ordinary thematical prescriptions and the provisions made by ecclesiastical and/or royal power.

KEYWORDS: Brotherhood documentation; Livros de Compromisso; irmandades in Minas 